\title{
PEMANFAATAN MEDIA SOSIAL SEBAGAI DIGITAL MARKETING UMKM DI KECAMATAN TEMBALANG SEMARANG
}

\author{
Nurtriana Hidayati ${ }^{1}$, Prind Triajeng Pungkasanti ${ }^{2}$, Nur Wakhidah ${ }^{3}$ \\ ${ }^{1,2,3}$ Jurusan Teknologi Informasi, Universitas Semarang \\ E-mail: ${ }^{1}$ anna@usm.ac.id, ${ }^{2}$ prind@usm.ac.id, ${ }^{3}$ ida@usm.ac.id
}

\begin{abstract}
Abstrak
Pemanfaatan teknologi informasi sudah merambah ke bidang digital marketing bagi para pelaku usaha. Salah satu alat digital marketing adalah media sosial. Media sosial inilah yang dapat membantu bagi para pelaku usaha dalam melakukan promosi dan penjualan produk, salah satunya adalah pelaku UMKM. Permasalahan yang dihadapi para pelaku UMKM khususnya UMKM yang ada di Kecamatan Tembalang semarang adalah penyebaran promosi masih menggunakan cara konvensional dengan cara penyebaran brosur, mengikuti bazar, membuka lapak, dan promosi dari mulut ke mulut. Hal ini menyebabkan jangkauan daerah pemasaran dan penjualan produk ruang lingkupnya kecil. Sehingga perkembangan bisnis para pelaku UMKM tidak berkembang pesat. Hal ini mempengaruhi pendapatan yang tidak meningkat, jumlah produk yang dijual tidak meningkat dan ruang lingkup wilayah pemasaran tidak luas, selain itu berpengaruh pada besarnya biaya operasional untuk promosi dan penjualan produk. Dengan adanya kegiatan pelatihan kepada pelaku UMKM di Kecamatan Tembalang Semarang nantinya para pelaku UMKM dapat memanfaatkan media sosial sebagai alat bantu digital marketing sehingga cakupan wilayah promosi menjadi luas dan membantu dalam melakukan penjualan produk.
\end{abstract}

Kata kunci:, pelatihan, digital marketing, media sosial

\begin{abstract}
The use of information technology has penetrated into the field of digital marketing for businesses. One digital marketing tool is social media. It is this social media that can help businesses in promoting and selling products, one of which is the MSME. The problem faced by MSME, especially MSME in Tembalang District of Semarang is that the promotion is still using conventional methods by distributing brochures, following bazaars, opening shanties, and word of mouth promotions. This causes the scope of marketing and product sales areas to be small in scope. So that the business development of MSME do not develop rapidly. This affects income that does not increase, the number of products sold does not increase and the scope of the marketing area is not broad, but it also affects the amount of operational costs for product promotion and sales. With the existence of training activities for MSME in the Tembalang District of Semarang, MSME will be able to utilize social media as a digital marketing stone tool so that the scope of the promotion area is broad and helps in selling products.
\end{abstract}

Keywords:, workshop, digital marketing, social media

\section{PENDAHULUAN}

Sebagian besar masyarakat Indonesia bahkan masyarakat dunia sudah menerapkan teknologi informasi dalam segala bentuk kehidupan. Hal ini disebabkan karena teknologi informasi memberikan kemudahan dalam menyajikan informasi dengan cepat. Teknologi 
informasi adalah suatu studi, perancangan, implementasi, pengembangan, dukungan atau manajemen sistem inforrmasi berbasi komputer, terkhususnya pada aplikasi perangkat keras dan perangkat lunak komputer [1]. Ada juga yang menyatakan bahwa teknologi informasi adalah seperangkat alat yang membantu anda bekerja dengan informasi dan melakukan tugas-tugas yang berhubungan dengan pemasaran informasi [2].

Pemanfaatan teknologi informasi tidak hanya terfokus pada bidang administrasi yang ada disebuah instansi, perusahaan, maupun organisasi. Namun pemanfaatan teknologi informasi sudah merambah kebidang digital marketing bagi para pelaku usaha. Hal ini disebabkan karena pemanfaatan teknologi informasi debagai alat digital merketing memudahkan masyarakat dalam melakukan penyebaran promosi yang jangkauannya lebih luas dan memudahkan bagi para pelaku usaha dalam melakukan transaksi penjualan produk. Digital marketing adalah kegiatan pemasaran termasuk branding yang menggunakan berbagai media berbasis website. Sebagai contoh adalah blog, website, adwords, dan berbagai macam jaringan sosial media [3]. Selain itu digital marketing merupakan perkembangan dunia digital untuk melakukan periklanan yang tidak digembar gemborkan secara langsung akan tetapi memiliki efek yang sangat berpengaruh [4]. Adapun kelebihan digital marketing antara lain: (1) kecepatan penyebaran; (2) kemudahan evaluasi; (3) jangkauan lebih luas; (4) murah dan efektif; dan (5) membangun nama brand.

Berdasarkan kelebihan digital marketing yang sudah disebutkan tersebut maka disimpulkan digital marketing membantu para pelaku usaha dalam melakukan promosi dan penjualan produk. Salah satu bagian dari teknologi informasi yang dapat digunakan sebagai alat digital marketing adalah media sosial.

Media sosial adalah segala bentuk media komunikasi interaktif yang memungkinkan terjadinya interaksi dua arah dan umpan balik [5]. Sedangkan pengertian lain media sosial adalah media yang digunakan oleh konsumen untuk berbagi teks, gambar, suara, dan video informasi baik dengan orang lain maupun perusahaan dan vice versa [6]. Media sosial inilah yang dapat membantu bagi para pelaku usaha dalam melakukan promosi dan penualan produk.

Usaha Mikro, Kecil, dan Menengah (UMKM) adalah Usaha Kecil (UK), termasuk usaha Mikro (UMI) adalah entitas usaha yang mempunyai kekayaan bersih paling banyak Rp. 200.000.000, tidak termasuk tanah dan bangunan tempat usaha dan memiliki penjualan tahunan paling banyak Rp. 1.000.000.000. sementara itu, Usaha Menengah (UM) merupakan entitas usaha milik warga negara Indonesia yang memiliki kekayaan bersih lebih besar dari Rp. 200.000.000 s.d Rp. 10.000.000.000 tidak termasuk tanah dan bangunan [7].

UMKM yang ada di Kecamatan Tembalang Semarang merupakan salah satu organisasi UMKM percontohan yang ada di Kota Semarang. Hal ini disebabkan karena UMKM lainnya belum terorganisir dengan baik seperti UMKM di Kecamatan Tembalang Semarang. Namun permasalah yang dihadapi para pekalu UMKM khususnya UMKM yang ada di Kecamatan Tembalang semarang adalah penyebaran promosi masih menggunakan cara konvensional dengan cara penyebaran brosur, mengikuti bazar, membuka lapak, dan promosi dari mulut ke mulut. Hal ini menyebabkan jangkauan daerah pemasaran dan penjualan produk ruang lingkupnya kecil. Sehingga perkembangan bisnis para pelaku UMKM tidak berkembang pesat. Hal ini mempengaruhi pendapatan yang tidak meningkat, jumlah produk yang dijual tidak meningkat dan ruang lingkup wilayah pemasaran tidak luas, selain itu berpengaruh pada besarnya biaya operasional untuk promosi dan penjualan produk.

Dengan adanya kegiatan pelatihan kepada pelaku UMKM di Kecamatan Tembalang Semarang nantinya para pelaku UMKM dapat memanfaatkan media sosial sebagai alat bantu digital marketing sehingga cakupan wilayah promosi menjadi luas dan membantu dalam melakukan penjualan produk.

\section{METODE PELAKSANAAN}

Kegiatan pengabdian kepada masyarakat ini diawali dengan survey lapangan dan melakukan wawancara dengan mitra dan sebagai narasumber adalah koordinator UMKM wilayah Kecamatan Tembalang, Ibu Anisah. 
Selanjutnya tim pengabdian dan koordinator UMKM merumuskan permasalahan yang timbul, yaitu permasalahan pada penyebaran promosi yang masih menggunakan cara konvensional dengan cara penyebaran brosur, mengikuti bazar, membuka lapak, dan promosi dari mulut ke mulut. Hal ini menyebabkan jangkauan daerah pemasaran dan penjualan produk ruang lingkupnya kecil. Sehingga perkembangan bisnis para pelaku UMKM tidak berkembang pesat. Hal ini mempengaruhi pendapatan yang tidak meningkat, jumlah produk yang dijual tidak meningkat dan ruang lingkup wilayah pemasaran tidak luas, selain itu berpengaruh pada besarnya biaya operasional untuk promosi dan penjualan produk.

Solusi yang ditawarkan dalam kegiatan ini adalah memberikan peningkatan pengetahuan tentang pemanfaatan media sosial sebagai digital marketing di Kecamatan tembalang semarang.

Metode pelaksanaan yang digunakan dalam pemanfaatan media sosial sebagai digital marketing di Kecamatan Tembalang Semarang adalah pelatihan yang akan diberikan dalam bentuk praktikum secara langsung, dengan mekanisme tiap peserta pelatihan menggunakan komputer yang nantinya digunakan sebagai alat untuk mempratekan materi pelatihan seperti menciptakan konten, mendistribusikan konten, membuat timeline konten, mengatur tampilan gambar atau foto dari produk yang akan dipasarkan. Selain itu pelatihan ini juga membahas tentang bagaimana cara memilih dan memanfaatkan media sosial sehingga dapat digunakan sebagai alat bantu digital marketing yang dapat membantu para pelaku UMKM dalam melakukan penyebaran wilayah promosi dan membantu dalam penjualan produk.

Untuk tempat pengabdian masyarakat ini berada di laboratorium komputer M.2.1 Fakultas Teknologi Informasi dan Komunikasi Universitas Semarang yang dilaksanakan pada hari Kamis, 04 Juni 2020. Kegiatan ini berlangsung lebih kurang selama empat jam yaitu 08.00 - 12.00 wib dan diikuti oleh 14 peserta dari berbagai jenis UMKM di Kecamatan Tembalang Semarang.

\section{HASIL DAN PEMBAHASAN}

Kegiatan pengabdian yang berlangsung lebih kurang selama 4 jam terdiri dari beberapa kegiatan berikut: (1) 15 menit diawali dengan sambutan Ketua tim pengabdian, (2) 15 menit selanjutnya digunakan untuk pra test peserta (3) 120 menit pemaparan materi pemanfaatan media social "Instagram" sebagai digital marketing yang dapat dilihat pada Gambar 1. (4) 75 menit digunakan dalam sesi tanya jawab tampak pada Gambar 2. (5) 15 menit terakhir digunakan untuk post test dan foto bersama dari kegiatan pengabdian tampak pada Gambar 3 .

Pemanfaatan media social instagram pada pelaku UMKM sebanyak 14 peserta yang berasal dari beragam jenis UMKM di Kecamatan Tembalang Semarang tampak belum maksimal, hal ini terlihat dari hasil pra test yang diberikan pada peserta pengabdian di awal kegiatan pengabdian.

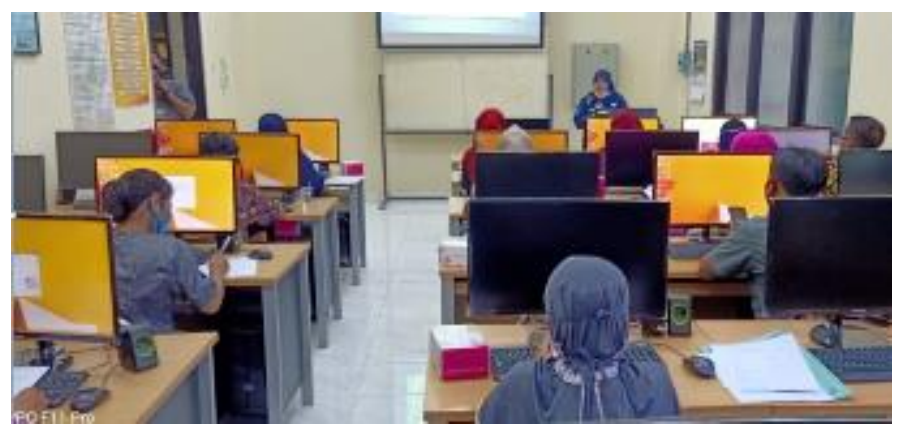

Gambar 1. Pemaparan Materi 
Kemudian dilakukan pemaparan materi berupa pengenalan media social instagram untuk bisnis, kegiatan ini tampak pada Gambar 1. Sebagian besar peserta pengabdian sudah mengenal aplikasi instagram, namun penggunaan instagram belum maksimal digunakan untuk kepentingan bisnis. Bahasan yang tercakup dalam materi ini adalah pemasaran konten pada instagram. Content marketing adalah strategi pemasaran dimana kita merencanakan, membuat dan mendistribusikan sebuah konten. Materi ini bertujuan untuk mengenalkan kepada peserta bagaimana membuat konten yang menarik sasaran untuk mengenal bisnis pelaku UMKM sehingga mampu mendorong minat mereka menjadi customer. Selain pemasaran konten, peserta juga dikenalkan bagaimana cara penggunaan hastag.

Peserta pengabdian terlihat tampak antusias dalam mengikuti kegiatan ini, beberapa pertanyaan dilontarkan peserta dalam sesi tanya jawab yang dapat dilihat pada Gambar 2.

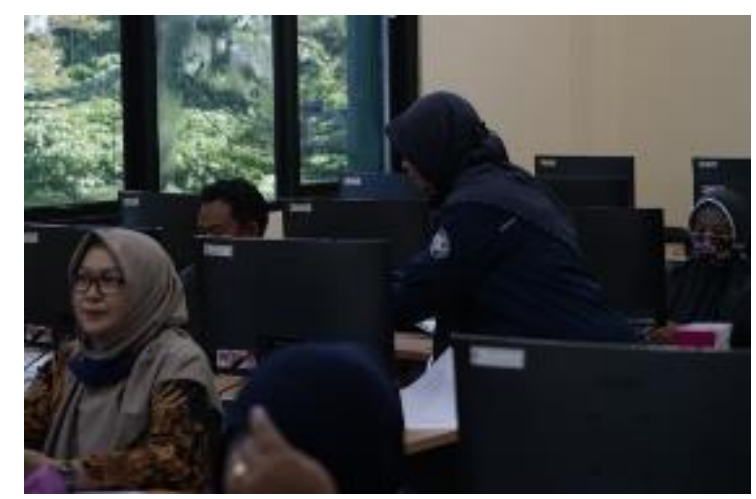

Gambar 2. Pelaksanaan Kegiatan Pengabdian sesi Tanya Jawab

Evaluasi keberhasilan dari pelaksanaan pengabdian ini dilakukan pada setiap sesi kegiatan. Sesi pemahaman awal peserta kegiatan menggunakan kuisioner pra test. Setelah sesi pemaparan materi dan sesi tanya jawab, tim pengabdian memberikan kuisioner post test untuk mengetahui peningkatan pemahaman peserta. Hasil yang diperoleh pada pra post test dengan 8 soal yang ada, dapat dilihat pada table 1 .

Tabel 1. Hasil Pra Post Test

\begin{tabular}{|c|l|c|c|}
\hline No & \multicolumn{1}{|c|}{ Nama Peserta } & Pra & Post \\
\hline 1 & Bambang Priyanto & 3 & 8 \\
\hline 2 & Titin Harliyanti & 2 & 3 \\
\hline 3 & Wahyu Krismiati & 6 & 8 \\
\hline 4 & Rina Kusumaningsih & 3 & 8 \\
\hline 5 & Tresna Yulianti & 5 & 6 \\
\hline 6 & Ita Madurini Astiti & 6 & 8 \\
\hline 7 & Ngatiyo & 4 & 7 \\
\hline 8 & Siti Prahperwani & 4 & 8 \\
\hline 9 & Ermi Hari Aliyani & 4 & 8 \\
\hline 10 & Nurin Syihabul Millah & 5 & 8 \\
\hline 11 & Weni Pungki Susilowati & 6 & 8 \\
\hline 12 & Kristiyanti & 7 & 8 \\
\hline 13 & Sunarwo & 3 & 7 \\
\hline 14 & Anisah & 4 & 8 \\
\hline
\end{tabular}


Hasil grafik kuisioner pra post test kegiatan pengabdian kepada masyarakat dengan judul Pemanfaatan Media Sosial Sebagai Digital Marketing UMKM Di Kecamatan Tembalang Semarang tampak pada Gambar 3. Hasil pra post test peserta menunjukkan peningkatan pemahaman atau penguasaan materi. Terlihat capaian nilai tertinggi dari 8 soal diperoleh 10 peserta, sehingga penguasaan materi pada kegiatan pengabdian ini dapat dicapai sejumlah $71,4 \%$.

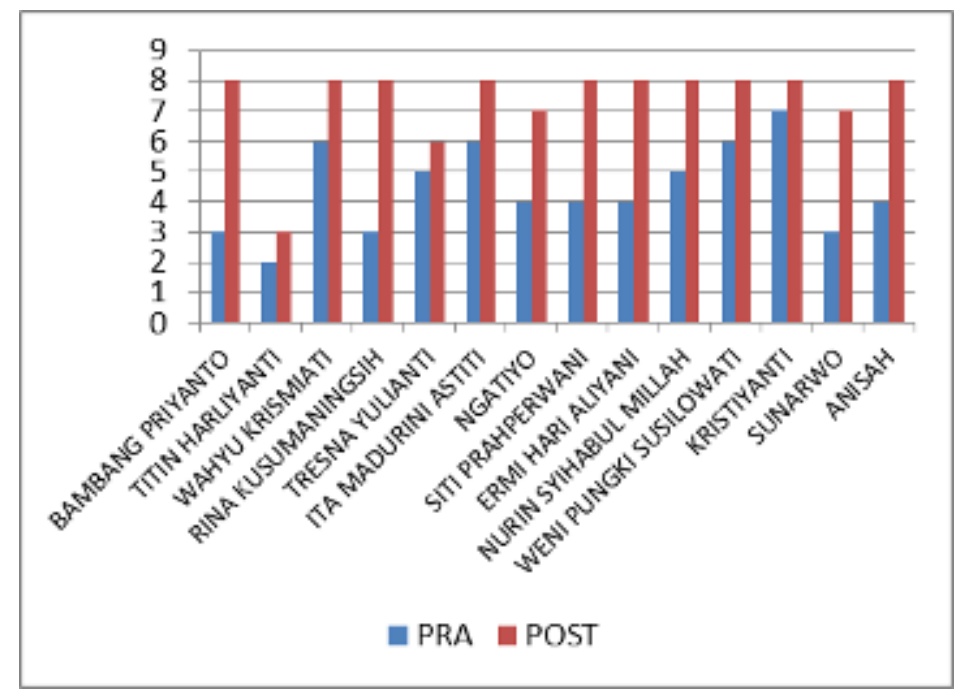

Gambar 3. Hasil Pra Post Test Peserta

Sedangkan untuk melihat perbandingan rata-rata nilai pra post test peserta sebelumnya sejumlah $38 \%$ dan sesudahnya $62 \%$ dapat dilihat pada Gambar 4 .

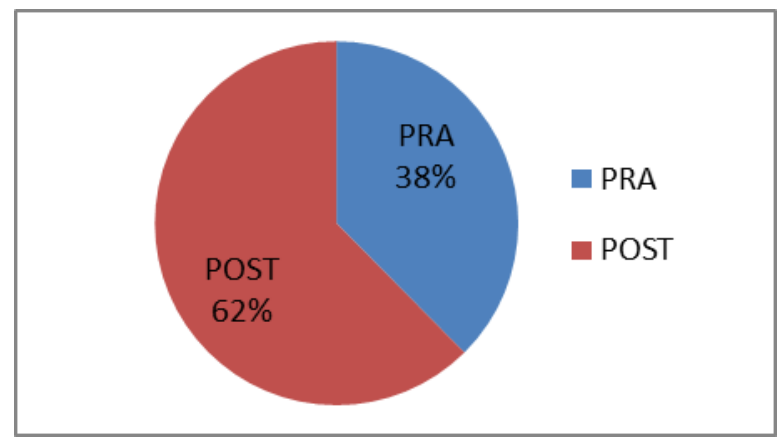

Gambar 4. Perbandingan Rata-rata Nilai Pra Post Test Peserta

Indikator keberhasilan kegiatan pengabdian ini adalah respon positif para peserta yang tampak antusias mengikuti setiap sesi selama kegiatan pengabdian ini berlangsung. Sebannyak $71,4 \%$ peserta menyatakan kegiatan pengabdian ini dapat meningkatkan pengetahuan para pelaku UMKM dalam hal pemanfaatan media sosial sebagai digital marketing. Selain itu, para pelaku UMKM berharap adanya kegiatan berkelanjutan untuk dapat melakukan pendampingan antara tim pengabdian dan para pelaku UMKM. Akhir dari kegiatan ini ditutup dengan foto bersama tim pengabdian dan para peserta seperti yang tampak pada Gambar 5. 


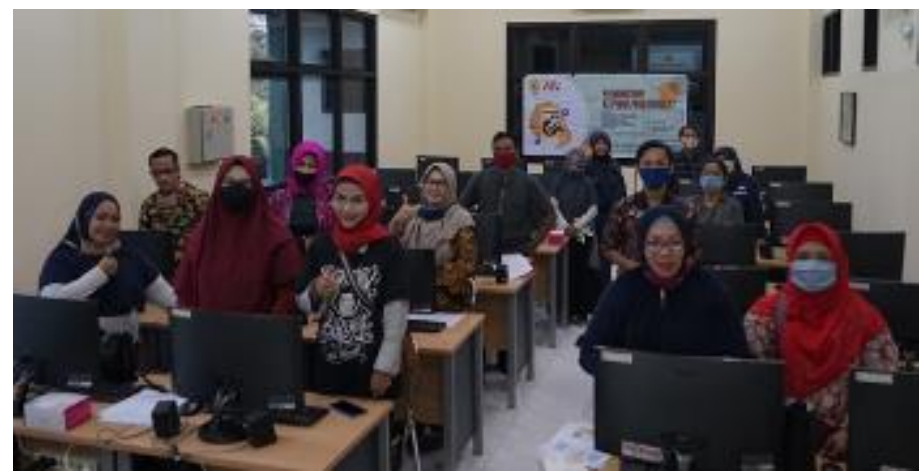

Gambar 5. Foto Bersama Tim Pengabdian dan para peserta

\section{KESIMPULAN DAN SARAN}

Dari kegiatan pengabdian ini, maka diperoleh beberapa kesimpulan antara lain: (1) kegiatan pelaksanaan pengabdian berjudul Pemanfaatan Media Sosial Sebagai Digital Marketing UMKM Di Kecamatan Tembalang Semarang berjalan dengan lancar dan sesuai dengan rencana (2) respon positif para peserta yang tampak antusias mengikuti setiap sesi selama kegiatan pengabdian ini berlangsung (3) meningkatnya pengetahuan para pelaku UMKM dalam hal pemanfaatan media sosial sebagai digital marketing sebanyak 71,4\%.

Saran pada kegiatan pengabdian ini adanya kegiatan berkelanjutan dan dikembangkan dengan pembuatan aplikasi yang dapat membantu para pelaku UMKM dalam mencatat transaksi jual beli.

\section{DAFTAR PUSTAKA}

[1] A. Susanto, Sistem Informasi Akuntansi dan Sistem Informasi Manajemen, Perdana. Bandung: Lingga Jaya, 2013.

[2] A. Kadir and T. C. Triwahyuni, Pengantar Teknologi Informasi, Revisi. Yogyakarta: Andi, 2013.

[3] R. Sanjaya and J. Tarigan, Creative Digital Marketing. Jakarta: Elex Media Komputindo, 2009.

[4] Heidrick and Struggles, The Adoption of Digital Marketing in Financial. Services Under Crisis, 2009.

[5] M. L. Kent, Directions in Social Media for Professional and Scholars, Dalam R L. Thousand Oaks: Sage, 2013.

[6] P. Kotler and L. K. Kevin, Marketing Management, 14th ed. United States of America: Pearson, 2016.

[7] K. K. dan HAM, "Laporan Kinerja Kementerian Koperasi Dan UKM Tahun 2014," 2015. 